\title{
BIEDA I WYKLUCZENIE - NOWE KONTEKSTY
}

Zasadniczym celem niniejszych rozważań jest analiza nowych kontekstów, mechanizmów i skutków starego zjawiska: wykluczenia, marginalizacji ludzi biednych. Truizmem jest stwierdzenie, że w ostatnich latach czy dekadach wiele się zmieniło - także w naszym odniesieniu do dóbr materialnych. Zmiana ta rodzi bardzo daleko idące i różnorodne konsekwencje: społeczne, pedagogiczne i moralne. Uchwycenie mechanizmów zmian wydaje się konieczne, żeby myśleć o profilaktyce i łagodzeniu (przynajmniej tych najbardziej dotkliwych) skutków. W tej dziedzinie chrześcijaństwo może odegrać niezwykle cenną rolę w społeczeństwie.

\section{BIEDA A TOŻSAMOŚĆ. JESTEM TYM, CO NOSZĘ}

Zasoby materialne (bogactwo) w zasadzie od zawsze były istotnym elementem stratyfikacji społecznej, jednym z trzech - wzajemnie

* Mgr Mateusz Mazurek - teolog, absolwent Papieskiej Akademii Teologicznej w Krakowie, katecheta w gimnazjum, doktorant Uniwersytetu Pedagogicznego im. KEN w Krakowie (Mateusz.mazurek83@o2.pl). 
powiązanych - dóbr rzadkich: władzy, prestiżu i zasobów właśnie. Od zawsze, a przynajmniej odkąd ludzkość wyszła ze zbieracko-łowieckiego etapu, bogaci czują się lepsi niż biedni. Może nie licząc wyjątków: np. mnichów ascetów, dla których właśnie ubóstwo było swoistym „powodem do dumy" - elementem budowania tożsamości i poczucia własnej wartości. Niekiedy - np. przez zwolenników ruchów lewicowych, bieda była ważnym, podkreślanym elementem tożsamości, ale nie była tu traktowana jako element pozytywny, raczej jako wynik niesprawiedliwych stosunków społecznych, które należy zmienić. Od wieków posiadanie i gromadzenie dóbr materialnych miało wymiar nie tylko użytecznościowy, ale i symboliczny. Wyrazem tego ostatniego był np. (zdaniem Jeana Baudrillarda zachowany, choć w zmienionej formie, do naszych czasów) rytuał potlaczu - widowiskowego niszczenia zasobów ${ }^{1}$. W naszych czasach pojawiają się jednak nowe aspekty zjawiska i specyficzne - związane przede wszystkim z kulturą konsumpcyjną - mechanizmy wykluczania ze względu na biedę. Niektóre z nich będą przedmiotem poniższych rozważań.

O ile bogactwo od wieków było elementem budowania społecznej pozycji, prestiżu i tożsamości, a posiadane dobra materialne rzutowały na indywidualne poczucie własnej wartości, to prawdopodobnie nigdy nie był to element tak istotny - w zasadzie jedyny. W społeczeństwie konsumpcyjnym natomiast nabiera nowego, znacznie większego znaczenia, z co najmniej kilku względów. W tradycyjnych społecznościach tożsamość była czymś w dużej mierze dziedziczonym, zastanym: człowiek, który urodził się chłopem spod Rzeszowa, najczęściej umierał jako chłop spod Rzeszowa i przez całe życie znał prostą i jednoznaczną odpowiedź na pytanie „kim jestem?". Wyznaczały ją - obok płci - przynależności: do rodziny, społeczności lokalnej, wspólnoty wyznaniowej, klasy społecznej itd. W znakomitej większości dziedziczone i zdeterminowane na całe życie. Nie wydaje się dla niniejszych rozważań konieczne dokładne opisywanie wad takiego stanu rzeczy - z których być może największą było drastyczne ograniczenie możliwości awansu społecznego. Istotne jest natomiast dostrzeżenie zmiany - dziś, w społeczeństwach ponowoczesnych, tożsamość jest czymś znacznie bardziej płynnym, konstruowanym i rekonstruowanym wciąż od

1 Por. J. Baudrillard, Społeczeństwo konsumpcyjne jego mity i struktury, tłum. S. Królak, Warszawa 2006. 
nowa, w znacznie większej mierze podlegającym modyfikacjom zależnym od decyzji jednostki. Niewątpliwie zakres jednostkowej wolności znacząco wzrósł, ale jak się okazuje, dawne regulatory zachowań nie zniknęły po prostu, tylko zostały zastąpione przez inny: modę (o czym będzie jeszcze mowa poniżej), a konstruowanie tożsamości współczesnego człowieka najczęściej polega na kupowaniu gotowych (najczęściej) uproszczonych scenariuszy tożsamościowych ${ }^{2}$. To właśnie konsumpcja stała się zasadniczym źródłem zasobów umożliwiających (lub ograniczających) autokreację - kupujemy towary, a wraz z nimi style życia, gotowe „pakiety tożsamości”, oznaki przynależności do grupy służące samookreśleniu, osobowości „określonej przez rzeczy” albo „wyrażającej się w rzeczach”4. Przedmioty, będące przede wszystkim znakami dystynktywnymi ${ }^{5}$, układają się w całe „konstelacje” oznaczające status i pozwalające odgrywać role społeczne. Kupujemy więc markę, a nie produkt $t^{6}$, gdyż w społeczeństwie konsumpcyjnym o wartości osoby (w społecznym odbiorze, a także w jej własnym poczuciu) decydują właśnie marki używanych produktów. Obowiązuje zasada ,jestem tym, co noszę”. Kim więc jestem, jeśli noszę ciuchy z second handu? O ile dawniej nawet człowiek nieposiadający przedmiotów - które dziś nazwalibyśmy prestiżowymi - wyznaczających status społeczny, zawsze

2 Por. T. Leszniewski, Moda i tożsamość. Dylematy współczesnego człowieka $w$ świecie konsumpcji, w: T. Szlendak, K. Pietrowicz, Rozkoszna zaraza. O rządach mody i kulturze konsumpcji, Wrocław 2007, s. 54.

${ }^{3}$ Por. M. Kempny, Wprowadzenie - konsumpcja wyzwaniem dla socjologii wspótczesnej, w: A Jawłowska, M. Kempny, Konsumpcja - istotny wymiar globalizacji kulturowej, Warszawa 2005, s. 9.

${ }^{4}$ Por. T. Szlendak, K. Pietrowicz, Moda, wolność i kultura konsumpcji, w: T. Szlendak, K. Pietrowicz, Rozkoszna zaraza, s. 25.

${ }_{5}^{5}$ Por. J. Baudrillard, dz. cyt., s. 63-65.

${ }^{6}$ Prowadzi to niejednokrotnie do zachowań niezrozumiałych z pragmatycznego punktu widzenia. Badane studentki Harvardu potrafiły np. w ślepym teście bezbłędnie wykazać różnice jakości płynu do oczyszczania twarzy za 5 i 25 dolarów, nie widząc jednocześnie różnicy jakości szminki za 5 i 20 dolarów. Co więc sprawia, że skłonne były kupować drogie szminki, a tanie płyny do demakijażu? Fakt, że szminka jest społecznie widoczna - używa się jej w przestrzeni publicznej. Zob. T. Szlendak, Supermarketyzacja. Religia i obyczaje seksualne młodzieży w kulturze konsumpcyjnej, Wrocław 2004, s. 86-89. Zob. też F. van Raaij, Konsumpcja postmodernistyczna, w: M. Lambkin, G. Foxall, F. van Raaij, B. Heilbrunn, Zachowania konsumenta. Koncepcje i badania europejskie, tłum. M. Zagrodzki, Warszawa 2001, s. 337. 
był członkiem jakiejś rodziny, społeczności lokalnej, narodu, grupy wyznaniowej itd., o tyle dziś, kiedy wszystkie te rzeczywistości tracą znaczenie, a wartość osoby wyznaczają symboliczne atrybuty, człowiek, który ich nie posiad,a może czuć się nikim.

\section{INDYWIDUALIZM}

Powyższe zmiany są w integralny sposób powiązane ze współczesnym indywidualizmem: atomizacją społeczeństwa, osłabieniem stabilności i trwałości rodziny ${ }^{7}$, osłabieniem więzi międzyludzkich i zmniejszeniem znaczenia wszelkich wspólnot. I znów można powiedzieć, że wynikające z tych zjawisk osłabienie kontroli społecznej wpływa na poszerzenie zakresu wolności, ale z drugiej strony kiedy słabną relacje, człowiek traci emocjonalne oparcie. Kiedy „znaczący inni” przestają być znaczący, człowiek traci możliwość zaspokojenia dzięki nim i ich uwadze jednej z najważniejszych potrzeb: poczucia wyjątkowości. Innymi słowy dawniej, kiedy człowiek był kimś ważnym i wyjątkowym dla kilku osób (najbliższej rodziny), ale te osoby były dla niego bardzo znaczące, to ich uwaga miała wystarczającą siłę, żeby zapewniać emocjonalne zaspokojenie $^{8}$. Dziś, kiedy relacje słabną - osoby znaczące stają się tylko nieznacznie ważniejsze niż pozostali, uwaga najbliższych traci swoją siłę - trzeba poszukiwać jej u „szerszej publiczności”. Ujmując rzecz nieco inaczej, w dużym uproszczeniu, mającym na celu wyraźniejsze pokazanie mechanizmu: skoro wszyscy otaczający nas ludzie staja się tak samo ${ }^{9}$ (mało)

7 Zob. np. Z. Szarota, Asystent rodziny. Między interwencjonizmem państwa a spolegliwym opiekuństwem - konteksty edukacyjne, „Edukacja” 116 (2011) 4, s. 56-57.

${ }^{8}$ Do tego dochodzi specyficznie polski aspekt, jakim jest eurosieroctwo, spowodowane emigracją zarobkową, której przyczyną jest między innymi rozbudzenie potrzeb konsumpcyjnych i relatywna deprywacja wynikająca z przyjmowania za punkt odniesienia bogatych społeczeństw zachodnich. Owszem, w wyniku wyjazdu rodziców $\mathrm{z}$ reguły następuje poprawa statusu materialnego rodziny, ale dzieje się to kosztem dramatycznego osłabienia więzi, oparcia emocjonalnego i poczucia bezpieczeństwa dziecka pozostawionego w Polsce.

9 Nie jest oczywiście tak, żeby najbliżsi stali się tak samo ważni, jak wszyscy inni, chodzi raczej o to, że im bardziej słabną więzi, tym bardziej zbliżamy się do takiego stanu, niż o to, że już go osiągnęliśmy. 
ważni, to nasze poczucie wartości, wyjątkowości zależy nie od tego, kto nas podziwia, ale jak wiele osób nas podziwia czy choćby zauważa. A tutaj bardzo ważne są „znaki - metki”.

Zachwyt i podziw w oczach jednej, ale bardzo ważnej, bliskiej osoby mógłby znaczyć więcej niż dziesiątków obcych, ale jeśli wszyscy znaczą dla mnie tak samo mało i są mi tak samo obcy...

\section{ATROFIA OBYCZAJU}

Trzecim elementem (zresztą też powiązanym z powyższymi) jest osłabienie znaczenia obyczaju. $Z$ trzech zasadniczych regulatorów zachowań, jakimi są: moda, obyczaj i prawo, tylko pierwszy i ostatni zachowują dzisiaj swoje znaczenie. O ile dotykające rozwinięte społeczeństwa zjawisko hipertrofii prawa ${ }^{10}$ nie wydaje się dla niniejszych rozważań szczególnie istotne, to atrofia obyczaju i przejście do „społeczeństwa opartego na modzie"11 jak najbardziej. Siła oddziaływania obyczaju wypływała z siły i znaczenia wspólnot wyznających określone wartości ${ }^{12}$. Dziś, gdy jednostka odpowiedzialna jest przed państwem, a nie przed wspólnotą ${ }^{13}$ (rodzinną czy jakąkolwiek inną), obyczaj jest wypierany z jednej strony przez prawo, a z drugiej przez modę, która odgrywa większą rolę niż kiedykolwiek wcześniej. Imperatywy związane z tym, że czegoś nie wypada robić lub że coś jest niemoralne, mają coraz mniejsze znaczenie. Coraz większego znaczenia natomiast nabiera czy coś jest modne. W efekcie trudniej budować swoją tożsamość a także poczucie wartości (zwłaszcza to odbite w lustrze społecznym) w oparciu o szlachetność charakteru. Usuwanie z pola świadomości moralności i obyczaju zamazuje znaczenie szlachetnych czynów i cech charakteru - w przypadku prawa liczy się tylko zgodność z nim lub jego złamanie. Niewiele tu miejsca na heroizm.

10 Por. R. Legutko, Złośliwe demony, Kraków 1999, s. 54.

11 Zob. np. Rozkoszna zaraza. O rządach mody i kulturze konsumpcji, red. T. Szlendak, K. Pietrowicz, Wrocław 2007.

12 Por. O. Speck, Być nauczycielem. Trudności wychowawcze w czasie zmian społeczno-kulturowych, tłum. E. Cieślik, Gdańsk 2005, s. 228.

13 Por. T. Szlendak, Architektonika romansu. O społecznej naturze miłości erotycznej, Warszawa 2002, s. 122. 
Prawo z natury swojej nie wskazuje na ideały moralne tylko na pewne minimum niedopuszczalnych zachowań. Oczywiście jeszcze mniej przestrzeni dla heroizmu czy cnót znajdujemy na gruncie mody. W społeczeństwach, w których obyczaj odgrywał istotną rolę, człowiek mógł zdobywać uznanie w oczach innych przez szlachetne czy wręcz bohaterskie czyny. W społeczeństwie opartym na modzie nie mają one wielkiego znaczenia; odpowiedni wygląd zaś - jak najbardziej. „Nieustanne odparowywanie wartości” powoduje wzrost znaczenia konsumpcji i symbolicznych atrybutów $^{14}$. Przejście do społeczeństwa opartego na modzie nie jest zmianą powierzchowną, biorąc pod uwagę, że moda rządzi w dziedzinach, które nie są oparte na obiektywnych przesłankach, nie wynikają z mocnych przekonań i głębokich motywów (jak ubiór, rozrywki, zachowania społeczne), w przeciwieństwie do takich dziedzin jak wiara religijna czy zainteresowania naukowe. Tutaj rządy mody mogą się rozwinąć dopiero wtedy gdy uniezależnią się one od głębszych ludzkich motywów, z których się zrodziły; trzeba zauważyć, że dziś moda wywiera tak wielki wpływ na ludzi, bo wielkie, niekwestionowane przekonania tracą na sile na rzecz przemijających, rozedrganych czynników ${ }^{15}$. Mamy więc do czynienia nie tylko ze zmianą regulatorów zachowań, ale z głęboką przebudową horyzontu aksjologicznego.

Przejście do społeczeństwa opartego na modzie ma jeszcze jeden wymiar - bardzo prozaiczny - ta coraz szybciej się zmienia. Nadążanie za nią wymaga przeznaczania znacznych środków na ten cel. Osoby niedysponujące nimi „zostają w tyle”, wyglądają staromodnie, passé - a dziś, zwłaszcza w niektórych środowiskach młodzieżowych, to niewybaczalne. Zresztą dość oczywista wydaje się konstatacja, że im większe znaczenie ma moda, tym istotniejsze dla poczucia własnej wartości jest to, jak się wygląda (a co z tym związane - ile jest się w stanie na ten cel wydać).

${ }^{14}$ Por. np. M. Jary, Wyznaczanie i tropienie trendów w kulturze konsumpcyjnej - kontekst nowych mediów, w: Wokót mediów ery Web 2.0, red. B. Jung, Warszawa 2010, s. $100-101$.

15 Por. G. Simmel, Filozofia mody, w: Socjologia. Lektury, red. P. Sztompka, M. Kucia, Kraków 2005, s. 274-276. 


\section{ILE JESTEM WART(A)?}

W czasach, kiedy tożsamość określają przedmioty, obyczaj i cnoty moralne tracą na znaczeniu, a uznania (czy chociażby dostrzeżenia) poszukujemy coraz bardziej rozpaczliwie (bo na bezcenny dar uwagi ze strony najbliższych coraz rzadziej możemy liczyć), realizacji podstawowych (zwłaszcza jeśli jesteśmy przedstawicielem młodego pokolenia) potrzeb: uznania, docenienia, dostrzeżenia można szukać na dwóch drogach. Jedna $\mathrm{z}$ nich to statusotwórcze gadżety, druga to atrakcyjność seksualna. O pierwszej była mowa powyżej. Warto więc krótko dookreślić drugą.

Żyjemy w kulturze, w której pojęcia miłości czy seksualności zostały skomercjalizowane ${ }^{16}$, „ociekającej seksem”17, od ponad pół wieku zalewanej przez „porno-pop kulturę"18. Z jednej strony pornografia (coraz bardziej perwersyjna) staje się coraz łatwiej dostępna ${ }^{19}$, kształtuje wyobrażenia i oczekiwania użytkowników ${ }^{20}$ (głównie mężczyzn), a z drugiej strony cała kultura masowa (ulegająca „pornografizacji” ${ }^{21}$ ) wysyła do kobiet jednoznaczny sygnał: sensem twojego życia i podstawą twojej wartości jest atrakcyjność seksualna. Amerykańskie Towarzystwo Psychologiczne określa to zjawisko „seksualizacją"22 - w uproszczeniu proces polega na

16 Por. np. M. Albrow, Globalizacja: teoretyczne aspekty zmian, w: Socjologia. Lektury, s. 687; T. Szlendak, Architektonika romansu, s. 276-281.

17 Por. T. Szlendak, T. Kozłowski, Naga małpa przed telewizorem. Popkultura $w$ świetle psychologii ewolucyjnej, Warszawa 2008, s. 151; zob. też. np. J. Baudrillard, dz. cyt., s. 193-194.

18 Por. D. Bell, Kulturowe sprzeczności kapitalizmu, Warszawa 1998, s. 86-87.

19 Por. Raport Amerykańskiego Towarzystwa Psychologicznego (American Psychological Association) na temat seksualizacji dziewcząt, tłum. E. Konfol, Warszawa 2013, online: https://www.google.pl/search? client=opera\&q=seksualizacja+definicja+raport+o +seksualizacji\&sourceid=opera\&ie=UTF-8\&oe=UTF-8 [dostęp: 2016.01.04], s. 37-40; Vademecum skutecznej profilaktyki. Przewodnik dla samorządowców i praktyków oparty na wynikach badań naukowych, red. Sz. Grzelak, Warszawa 2015, s. 19, 60.

${ }^{20}$ G. Dines nazywa ten przekaz „pornoideologią” i stwierdza, że jest ona sączoną kobietom przez całą kulturę masową. Por. G. Dines, Pornoland. Jak skradziono naszą seksualność, tłum. K. Dajksler, Poznań 2012, s. 179.

${ }^{21}$ Odebrana niewinność. Raporty o seksualizacji kobiet $i$ dziewcząt we wspótczesnej kulturze, red. E. Rżysko, Warszawa 2013, s. 79; zob. także G. Dines, Pornoland; T. Szlendak, Supermarketyzacja, s. 153-170.

22 Por. Raport Amerykańskiego Towarzystwa, s. 12. 
tym, że kultura wielokanałowo wysyła spójny przekaz: kobieta to wyłącznie obiekt seksualny ${ }^{23}$, a kobiety internalizują go i same zaczynają siebie tak postrzegać i traktować ${ }^{24}$.

W efekcie nakreślonych powyżej zmian społecznych ciało stało się przedmiotem konsumpcyjnym, jednocześnie kapitałem i fetyszem ${ }^{25}$, traktowanym przedmiotowo i popadającym w schemat wartości użytkowej/wymiennej ${ }^{26}$. Przekształcenie siebie i własnego ciała w artykuł handlowy pozwala, by ludzie byli „konsumowani” jak inne wyroby na $\mathrm{rynku}^{27}$. Dzięki temu możliwe stało się generowanie ogromnych zysków $\mathrm{z}$ seksualności ${ }^{28}$. Rzeczywiście sfera seksualna jest intensywnie eksploatowana, a cała kultura nabiera ostentacyjnie seksualnego charakteru. Sama seksualność została skomercjalizowana i jest przedmiotem konsumpcji ${ }^{29}$.

\section{PROSTYTUCJA - IDEALNE POŁĄCZENIE}

Jeżeli mamy do czynienia z komercjalizacją wszystkiego (z seksualnością na czele), a młoda osoba widzi przed sobą tylko dwa sposoby,

${ }^{23}$ Wg Raportu Amerykańskiego Towarzystwa Psychologicznego w filmach młodzieżowych mężczyźni stanowią 72\% wypowiadających się bohaterów. Milczące bohaterki nie mają zbyt wielu możliwości zaprezentowania zalet intelektu czy charakteru, ale najwidoczniej nie po to występują $\mathrm{w}$ filmie. Podobnie sytuacja przedstawia się w teledyskach (w 57\% kobieta występowała wyłącznie jako ozdobny obiekt seksualny, a tam, gdzie była wokalistką, prawie zawsze prezentowała się w seksualnie sugestywnych strojach i pozach), w grach komputerowych i czasopismach (w magazynach ponad połowa wizerunków kobiet przedstawia je jako „ozdobnik”), w świecie zabawek i w reklamie (zależnie od grupy, do której adresowany jest przekaz, kobiety dwu-trzykrotnie częściej przedstawiane są jako obiekt seksualny niż mężczyźni). Por. Raport Amerykańskiego Towarzystwa, s. 15-20.

${ }^{24}$ To z kolei rodzi cały szereg negatywnych zjawisk zdrowotnych, psychicznych i emocjonalnych jak zaburzenia odżywiania, depresje; czy intelektualnych - gorsze wyniki w matematyce i innych dziedzinach poznawczych wymagających logicznego myślenia i zdolności przestrzennych. Raport Amerykańskiego Towarzystwa, s. 27-31.

${ }^{25}$ Por. J. Baudrillard, dz. cyt., s. 169-170.

${ }^{26}$ Por. tamże, s. 203.

27 Prowadzi to „konkurencji piękności, a w skrajnych wypadkach do prostytucji”.

Por. F. van Raaij, Konsumpcja postmodernistyczna, s. 340.

${ }^{28}$ Por. J. Baudrillard, dz. cyt., s. 180.

${ }^{29}$ Por. tamże, s. 193-195. 
żeby poczuć się kimś wartościowym: posiadanie drogich rzeczy lub atrakcyjność seksualną; to w dość oczywisty sposób narzuca się wniosek, że prostytucja jest doskonałym sposobem połączenia obu. Można więc niestety z dużym prawdopodobieństwem przewidywać narastanie tego zjawiska. Żeby zaistnieć w grupie rówieśniczej, być akceptowanym, trzeba mieć markowe rzeczy - prostytucja jest sposobem na ich zdobycie ${ }^{30}$. Jeżeli znane jest zjawisko „zabijania dla produktu” (morderstwa dokonywane $\mathrm{w}$ celu zdobycia wymarzonych adidasów) ${ }^{31}$, to prostytuowanie się w celu zdobycia markowych rzeczy nie wydaje się czymś dziwnym czy nieprawdopodobnym. Oczywiście jest to zajęcie bardzo poniżające, ale w świetle konsumpcyjnej aksjologii znacznie bardzie poniżające wydaje się nieposiadanie markowych przedmiotów.

Można więc przewidywać, że „podaż” na rynku prostytucji nieletnich będzie rosła. „Popyt” rośnie cały czas. Sprzyjają temu procesy społeczne, w wyniku których dzieci dorośleją, a dorośli dziecinnieją. Zacierająca się granica między dzieckiem a dorosłym sprawia, że np. moda dziecięca staje się imitacją dorosłej - w podobny sposób eksponuje ciało, a z drugiej strony wśród dorosłych wszechpanująca staje się moda na szczupłe dziewczęce ciało traktowane jako seksowne. Współczesny kanon urody to wielkie oczy, pełne usta, niewinne twarze, szczupłe ciała, drobne piersi - jednym słowem Lolita ${ }^{32}$. Wpływ na ukształtowanie się takiego kanonu piękna ma także pornografia dziecięca i pseudodziecięca (w której pełnoletnie aktorki ucharakteryzowane są na dzieci), przedstawiająca także profesjonalnie pod względem psychologicznym opracowane scenariusze wykorzystania dziecka ${ }^{33}$ i tworząca (przynajmniej potencjalnie) rynek „handlu dziećmi” ${ }^{34}$.

${ }^{30}$ Por. A. Kowalik, Centrum handlowe jako nowa przestrzeń zabawy młodzieży, w: Wąż w raju. Zabawa w społeczeństwie konsumpcyjnym, red. R. Kantor, T. Paleczny, M. Banaszkiewicz, Kraków 2011, s. 110.

${ }^{31}$ Por. T. Szlendak, Supermarketyzacja, s. 92-93.

32 M. Bogunia-Borowska, Dziecko w kulturze konsumpcyjnej - infantylizacja kultury jako konsekwencja narodzin podmiotu rynkowego, w: A. Jawłowska, M. Kempny, Konsumpcja - istotny wymiar globalizacji kulturowej, Warszawa 2005, s. 177-180.

33 Por. G. Dines, Pornoland, s. 235-270.

${ }^{34}$ Raport Amerykańskiego Towarzystwa Psychologicznego, s. 37. Na marginesie warto wspomnieć też o działalności organizacji (jak NAMBLA NAWGLA) protestujących 


\section{BIEDA A EDUKACJA}

Do nowych aspektów wykluczania ze względu na biedę można zaliczyć jeszcze wpływ poczucia wstydu ludzi biednych (zwłaszcza dzieci i młodzieży) na reprodukcję społecznego rozwarstwienia. Wstyd z powodu ubóstwa, który - jak próbowano pokazać powyżej - nabiera dziś nowych wymiarów, może powodować niechęć do uczęszczania do szkoły, w której biedny uczeń czuje się wykluczony. W gospodarce opartej na wiedzy kapitał intelektualny jest kluczowym czynnikiem decydującym o pozycji na drabinie społecznej, rozwoju społeczeństw i jednostek ${ }^{35}$. Obniżenie osiągnięć edukacyjnych powoduje więc automatycznie drastyczne ograniczenie szans życiowych. Należy brać dodatkowo pod uwagę fakt, że bieda $\mathrm{w}$ połączeniu $\mathrm{z}$ nadmierną i nieumiejętnie udzielaną pomocą społeczną rodzi wyuczoną bezradność i roszczeniową postawę ${ }^{36}$, która w oczywisty sposób przenosi się na aktywność (czy raczej jej brak) nie tylko zarobkową, ale także edukacyjną. Jest to szczególnie widoczne i istotne współcześnie $\mathrm{z}$ dwóch powodów. Po pierwsze wiedza nie tyle powinna być przekazywana, co udostępniana i konstruowana przy aktywnej postawie uczącego się podmiotu $^{37}$. Postawie - dodajmy - obcej osobom dotkniętym syndromem wyuczonej bezradności. Dodatkowo dziś coraz większego znaczenia nabiera edukacja przez całe życie. Uczestnictwo edukacyjne dorosłych z jednej strony jest kluczowym elementem przeciwdziałania osuwaniu się w obszar marginalizacji społecznej, a z drugiej wymaga przełamywania bierności, otwartości wobec aktywności poznawczej ${ }^{38}$. I znowu nietrudno zauważyć, że są to postawy biegunowo odmienne od wyuczonej bezradności. Widać więc, jak wynikająca z biedy bierność podwójnie ogranicza osiągnięcia edukacyjne, a co za tym idzie szanse życiowe.

przeciw dyskryminacji dzieci pozbawionych prawa do wyrażania swojej seksualności w międzypokoleniowych związkach. Zob. M. Bogunia-Borowska, Dziecko w kulturze konsumpcyjnej, s. 178.

35 Z. Szarota, Egalitaryzacja dyplomów vs. elitaryzm merytokracji - wybrane aspekty uczestnictwa edukacyjnego dorosłych, „Edukacja Dorosłych” 67 (2012) 2, s. 10-12, $22-23$.

36 Por. Z. Szarota, Asystent rodziny, s. 49.

37 Por. Z. Szarota, Egalitaryzm dyplomów, s. 17-18.

38 Por. tamże, s. 18-19. 
Bezpłatna, publiczna (powszechnie dostępna) edukacja ma w złożeniu wyrównywać szanse - a przez to zmniejszać społeczne rozwarstwienie. W pewnym stopniu niewątpliwie wypełnia taką rolę, ale warto stawiać pytania, na ile skutecznie. Im większa będzie różnica jakości edukacji publicznej i prywatnej, a także im większe będzie znaczenie korepetycji, tym bardziej edukacja będzie narzędziem reprodukowania społecznego rozwarstwienia zamiast niwelowania go. Jeżeli więc zestawić ze sobą występujące od dawna, dobrze rozpoznane i opisane czynniki ograniczające prawdopodobieństwo osiągania sukcesów edukacyjnych przez biednych, takie jak: mniejszy kapitał kulturowy i niższe aspiracje z nowymi - jak wstyd i ryzyko wykluczenia spowodowane biedą czy wyuczona bezradność, to ideał wyrównywania szans wydaje się oddalać. Jeżeli dodatkowo jakość publicznej edukacji będzie się obniżać i coraz bardziej różnić od prywatnej, to szanse na wyrównywanie szans dramatycznie maleją.

\section{PODSUMOWANIE: W STRONĘ POSZUKIWANI ROZWIAZZAŃ}

Problemy wynikające z biedy są tak złożone i wieloaspektowe, że chyba nikomu nie udało się dotąd znaleźć kompleksowego i skutecznego rozwiązania. Poniższe słowa nie będą próbą wskazania go. Mają raczej na celu wskazanie pewnych kierunków działań, które mogłyby w pewnym stopniu przyczynić się do łagodzenia niekorzystnych skutków zjawisk opisanych w tym tekście.

\section{POMOC SPOŁECZEŃSTWA}

Dla problemu - nazwijmy go ogólnie poczucia niższości ludzi biednych - trudno upatrywać rozwiązania w pomocy socjalnej (nawet najbardziej rozbudowanej). Organizacje pomocowe musiałyby rozdawać wyznaczające status - a więc najdroższe i najnowocześniejsze gadżety. W polskich warunkach, tzn. w sytuacji, gdy nie wszyscy mają zapewnione zaspokojenie podstawowych potrzeb, próby takie byłyby wręcz niemoralne. Zresztą nawet w zamożniejszych społeczeństwach nie wydaje się to możliwe - bo „statusotwórcze” znaczenie kosztownych przedmiotów 
wynika właśnie z ich ceny, która uniemożliwia ich posiadanie. Stratyfikacja oparta na posiadanych przedmiotach poszukuje ciągle nowych oznak statusu. Nie wydaje się możliwe, żeby pomoc społeczna mogła kiedykolwiek za tym nadążyć. Jakkolwiek socjalne wsparcie ma znaczenie dla problemów opisanych w tym tekście. Po pierwsze może nieco łagodzić przepaść między bogatymi i biednymi, a przez to w pewnym stopniu podnosić poczucie własnej wartości tych drugich. Niezwykle istotne wydaje się jednak przemyślane udzielenie pomocy - tak, by nie uczyć beneficjentów roszczeniowości i bezradności, które jak starałem się pokazać powyżej, w dzisiejszych czasach okazują się szczególnie szkodliwe.

Niewątpliwie ważnym obszarem działań mających na celu przeciwdziałanie wykluczeniu ze względu na biedę jest edukacja. Z jednej strony rysuje się więc potrzeba zachęcania i tworzenia sprzyjających warunków do własnej aktywności edukacyjnej kształcenia przez całe życie, z drugiej zaś stała troska o podnoszenie jakości publicznej edukacji. I jeszcze jeden element - powrót (w wychowaniu) do starej, sprawdzonej maksymy: ora et labora - ukazującej, że to, co dostajemy (od Boga), nie powinno wykluczać naszego własnego wysiłku, a wręcz przeciwnie - w pewien sposób go zakłada. Powrót do tego sposobu myślenia może się okazać lekarstwem na coraz powszechniejszą postawę roszczeniową - z jej licznymi negatywnymi konsekwencjami (niektóre $\mathrm{z}$ nich zostały opisane powyżej).

\section{UWRAŻLIWIANIE BOGATYCH}

Wszystkie powyższe propozycje nakierowane były (w całości lub znacznej mierze) na ludzi biednych, ale należy pamiętać, że zjawisko wykluczenia ma zawsze dwie strony: ujmując rzecz najprościej - wykluczanych i wykluczających. Warto też pamiętać o tych drugich. Oprócz ukazywania im wyższych wartości i przekonywania, że ważniejsze to, co człowiek sobą reprezentuje i jakie wartości realizuje, niż to, ile dóbr materialnych posiada, ważne wydaje się też uczenie ich pewnej wrażliwości na drugiego człowieka, szczególnie pokrzywdzonego przez los. Sposobem na to może być angażowanie bogatych w mądrą działalność dobroczynną. Przykładem może być odbywająca się w Bielsku-Białej akcja, w ramach 
której zamożni mieszkańcy osobiście odwiedzali ubogie rodziny, którym mieli pomóc. Warto przytoczyć opis jednej sytuacji:

Te prezenty zaniósł rodzinie wnuk Anny, rozkapryszony nastolatek, który obrażał się na cały świat, gdy nie dostał najnowszego modelu komórki czy nowej gry komputerowej. Po raz pierwszy w życiu wszedł w świat ubóstwa, spotkał ludzi, którym brakuje podstawowych przedmiotów. Po powrocie do domu długo milczał i jakoś przestał wypytywać, co dostanie na gwiazdkę ${ }^{39}$.

\section{ALTERNATYWNE HIERARCHIE WARTOŚCl}

Jeżeli chodzi o - prawdopodobnie najpoważniejszy z poruszanych powyżej problemów - specyficzne dla kultury konsumpcyjnej problemy z tożsamością i poczuciem własnej wartości ludzi biednych, to niezwykle istotne wydaje się ukazywanie alternatywnych (wobec bogactwa) wartości, w oparciu na których można konstruować swoją tożsamość, uznanie u innych i szacunek do siebie samego. Ważną rolę ma tutaj szeroko rozumiane (a niestety dziś zmarginalizowane) wychowanie do wartości - ukazywanie znaczenia tych wyższych i zachęcanie do realizacji ich ${ }^{40}$. Głębokiego namysłu i ogromnej pracy wychowawczej wymaga doprowadzenie do stanu, w którym tak znane, że wręcz „wyświechtane” wezwanie Jana Pała II, żeby bardziej być niż więcej mieć, zamiast popularnym sloganem stanie się treścią życia (przynajmniej niektórych, bo naiwnością byłoby oczekiwać, żeby wszystkich) naszych wychowanków. To, że rzecz jest trudna, nie zmienia faktu, że potrzebna - jest to zadanie, z którego nie można zrezygnować. Można powiedzieć (parafrazując Jana Pawła II), że to jest dzisiaj nasze wychowawcze „Westerplatte”.

Żeby przez wychowanie można było ukazywać inne niż konsumpcyjna hierarchie wartości, muszą one funkcjonować w kulturze. Żeby

39 A. Grajewski, 12 okruchów, „Gość Niedzielny, nr 2 rok XCIII/ 10 stycznia 2016, s. 43.

${ }^{40}$ Na marginesie uwag o wychowaniu do wartości można wspomnieć, że szkoła wydaje się naturalną przestrzenią promowania wartości intelektualnych, które także mogą stanowić alternatywę dla dominacji tych związanych z konsumpcjonizmem i materializmem. 
ludzie (szczególnie młodzi) potrafili budować poczucie własnej wartości inaczej niż w oparciu na prestiżowych przedmiotach (lub atrakcyjności seksualnej), musi funkcjonować w społeczeństwie wyrazista alternatywa. Chrześcijaństwo wydaje się doskonale nadawać do tej roli. Jeżeli przyjrzeć się Kazaniu na Górze, to widać wyraźnie, że mamy do czynienia ze swoistym manifestem antykonsumpcyjnym. Oczywiście traktowanie biblijnego tekstu tylko w takich kategoriach byłoby niewybaczalnym spłyceniem, ale trudno nie zauważyć, że tożsamość człowieka kierującego się tym przesłaniem budowana jest w oparciu na zupełnie innych czynnikach niż władza, prestiż i zasoby.

W kontekście opisanych powyżej zjawisk świadectwo chrześcijan może się okazać niezwykle cenne dla społeczeństwa. Oczywiście pod warunkiem, że „nie będą oni brali wzoru z tego świata, lecz przemieniali się w swoim myśleniu" (por. Rz 12,2). Jest rzeczą oczywistą, że mówienie o wyższych wartościach w sytuacji, kiedy kochamy pieniądze tak samo jak wszyscy, nie okaże się zbyt skuteczne.

Streszczenie. Artykuł opisuje i analizuje nowe aspekty starego zjawiska: wykluczenia ze względu na biedę. W kulturze konsumpcyjnej zamożność odgrywa najważniejszą rolę w konstruowaniu tożsamości i budowaniu poczucia własnej wartości. W dzisiejszych czasach, gdy wszystkie inne wartości schodzą na dalszy plan, a wspólnoty, które dawniej nadawały tożsamość, tracą na znaczeniu, odpowiedź na pytanie „kim jestem?” zawarta jest w przedmiotach - prestiżowych symbolach statusu. Jeżeli rzeczy, które posiadam, decydują o tym, kim jestem - to nie posiadając nic wartościowego, mam podstawy czuć się bezwartościową osobą. Dla współczesnego (szczególnie młodego) człowieka rysują się dwie drogi: posiadanie prestiżowych gadżetów lub atrakcyjność seksualna. Połączenie obu stanowi prostytucja nieletnich - prawdopodobnie najbardziej dotkliwy skutek opisywanych tu procesów

Zapobieganie im wymaga przedstawienia atrakcyjnej alternatywy: konkurencyjnych wobec konsumpcyjnego systemów wartości (w oparciu na których można by było w inny sposób budować tożsamość i poczucie własnej wartości). Chrześcijaństwo ma tu do odegrania bardzo ważną rolę.

Słowa kluczowe: bieda; wykluczenie; prostytucja; edukacja.

Abstract. Poverty and exclusion - new contexts. The article describes and analyzes new aspects of an old phenomenon: of reason of the poverty. In the consumer culture wealth plays a particularly important role in the construction of identity and self- 
-esteem. Nowadays when all other values lose importance, and communities that once gave identity lose importance, the answer to the question of "who I am" is included in objects - prestigious symbols of the status. If objects determine who I am then not having them makes me feel like a worthless person. For the modern man (especially young) there are two ways to get respect and recognition: possession of prestigious gadgets or sexual attractiveness. A combination of both is prostitution of minors - probably the most painful result of the processes described here.

Prevention requires the presentation of an attractive alternative: other than the consumer value systems that allow in another way to build identity and self-esteem. Christianity has a very important role to play here.

Key words: poverty; exclusion; prostitution; education.

\section{BIBLIOGRAFIA}

Albrow, M., Globalizacja: teoretyczne aspekty zmian, tłum. K. Gilarek, w: red. P. Sztompka, M. Kucia, Socjologia. Lektury, Kraków 2005, s. 679-696.

Baudrillard, J., Społeczeństwo konsumpcyjne jego mity i struktury, tłum. S. Królak,Warszawa 2006.

Bell, D., Kulturowe sprzeczności kapitalizmu, tłum. S. Amsterdamski, Warszawa 1998.

Bogunia-Borowska, M., Dziecko w kulturze konsumpcyjnej - infantylizacja kultury jako konsekwencja narodzin podmiotu rynkowego, w: A. Jawłowska, M. Kempny, Konsumpcja - istotny wymiar globalizacji kulturowej, Warszawa 2005, s. 157-183.

Dines, G., Pornoland. Jak skradziono nasza seksualność, tłum. K. Dajksler, Poznań 2012. Grajewski, A., 12 okruchów, „Gość Niedzielny, nr 2 rok XCIII/ 10 stycznia 2016, s. 42-43. Honoré, C., Pod presją. Dajmy dzieciom święty spokój!, tłum. W. Mitura, Warszawa 2011. Jary, M., Wyznaczanie i tropienie trendów w kulturze konsumpcyjnej - kontekst nowych mediów, w: Wokół mediów ery Web 2.0, red. B. Jung Bohdan, Warszawa 2010, s. 91-114.

Kempny, M., Wprowadzenie - konsumpcja wyzwaniem dla socjologii współczesnej, w: A. Jawłowska, M. Kempny, Konsumpcja - istotny wymiar globalizacji kulturowej, Warszawa 2005, s. 7-14.

Kowalik, A., Centrum handlowe jako nowa przestrzeń zabawy młodzieży, w: Wąż w raju. Zabawa $w$ społeczeństwie konsumpcyjnym, red. R. Kantor, T. Paleczny, M. Banaszkiewicz, Kraków 2011, s. 93-111.

Legutko, R., Złośliwe demony, Kraków 1999.

Leszniewski, T., Moda i tożsamość. Dylematy współczesnego człowieka w świecie konsumpcji, w: T. Szlendak, K. Pietrowicz, Rozkoszna zaraza. O rzadach mody i kulturze konsumpcji, Wrocław 2007, s. 49-61.

Odebrana niewinność. Raporty o seksualizacji kobiet i dziewcząt we współczesnej kulturze, red. E. Rżysko, Warszawa 2013. 
Raport Amerykańskiego Towarzystwa Psychologicznego (American Psychological Association) na temat seksualizacji dziewcząt, tłum. E. Konfol, Warszawa 2013, online: https://www.google.pl/search?client=opera\&q=seksualizacja+definicja+raport+ o+seksualizacji\&sourceid=opera\&ie=UTF-8\&oe=UTF-8 [dostęp: 2016.01.04].

Simmel, G., Filozofia mody, w: Socjologia. Lektury, red. P. Sztompka, M. Kucia, Kraków 2005, s. 272-276.

Speck, O., Być nauczycielem. Trudności wychowawcze w czasie zmian społeczno-kulturowych, tłum. E. Cieślik, Gdańsk 2005.

Szarota, Z., Asystent rodziny. Między interwencjonizmem państwa a spolegliwym opiekuństwem - konteksty edukacyjne, „Edukacja” 116 (2011) 4, s. 49-65.

Szarota, Z., Egalitaryzacja dyplomów vs. elitaryzm merytokracji - wybrane aspekty uczestnictwa edukacyjnego dorostych, „Edukacja Dorosłych” 67 (2012) 2, s. 9-26.

Szlendak, T., Architektonika romansu. O społecznej naturze miłości erotycznej, Warszawa 2002.

Szlendak, T., Kozłowski, T., Naga małpa przed telewizorem. Popkultura w świetle psychologii ewolucyjnej, Warszawa 2008.

Szlendak, T., Supermarketyzacja. Religia i obyczaje seksualne młodzieży w kulturze konsumpcyjnej, Wrocław 2004.

Szlendak, T., Pietrowicz, K., Moda, wolność i kultura konsumpcji, w: T. Szlendak, K. Pietrowicz, Rozkoszna zaraza. O rzadach mody i kulturze konsumpcji, Wrocław 2007, s. 8-26.

Vademecum skutecznej profilaktyki. Przewodnik dla samorządowców i praktyków oparty na wynikach badań naukowych, red. Sz. Grzelak, Warszawa 2015.

van Raaij F., Konsumpcja postmodernistyczna, w: M. Lambkin, G. Foxall, F. van Raaij, B. Heilbrunn, Zachowania konsumenta. Koncepcje i badania europejskie, tłum. M. Zagrodzki, Warszawa 2001, s. 325-344. 